\title{
Media language under conditions of media convergence: linguistic and extra-linguistic periods of its development
}

\author{
Mauye K. Adyrbekova - Ekaterina A. Baranova - Anna A. Shnaider - \\ Albina R. Shaidullina - Elvira K. Sabaeva - Anvar N. Khuziakhmetov
}

DOI: 10.18355/XL.2019.12.04.09

\begin{abstract}
The issue of systematization of the media language experience, accumulated by various media companies in the media development in terms of media convergence, is becoming ever more relevant nowadays. The authors show the research to the period of the history of 20 years of the development process of media language in terms of media convergence. The comprehensive changes in media language are considered. They occur at various levels of the media institutions: at the media language level as a sphere of creative activity, at the level of media language as a profession (journalism), at the level of media language as a media system, at the level of media language as a moral and ethical institution of the society, and at the level of media language as a sphere of business. 2 periods of transformation of media language under condition of media convergence are described: I Period (from the mid-second half of the 1990s to the 2010s); II Period (from the 2013 to this day). In the article the linguistic and extralinguistic changes of media language that took place at the different stages of the development of media convergence are identified and analyzed.

Key words: media language, media discourse, media convergence, linguistic and extra-linguistic stages, online versions of mass media, mobile applications of mass media, UGC
\end{abstract}

\section{Introduction}

The media system has been systematically formed throughout the long period of history, since the appearance of the first printed publications in the 17th century. New types of media, such as news agencies, radio, and television has been developing as independent and self-sufficient units: including its own genre identity and unique features of the creation and distribution of content. A completely new stage of the development of the media language had begun at the end of the 20th and the beginning of the 21 st century. This process was followed by the development of the digitalization process (digitalization is from English, means 'integration of digital technologies'), as well as Internet and mobile technologies. The authors consider, that nowadays, after 20 years of development of the convergence process (in the second half of the 1990s, when media began to actively create Internet versions, which can be considered of the beginning of this process), the definition of the term "media convergence" (Quinn, Filak, 2005) should be approached through a detailed description of the sequential development of the process, considering and taking into account various external, extra-linguistic factors: national and cultural features of the country's development, legislation in the field of cross-media ownership, the level of development of the Internet and the number of Internet users, the development of the mobile industry and the ICT market, as well as the specifics of the media market (competition, target audience), and internal, linguistic factors: development of media language means and media content.

\section{Literature Review}

Despite the fact that the process of media convergence is well studied by various authors (Baranova, 2017; Dailey, Demo \& Spillman, 2005; Domingo, Salaverría,

XLinguae, Volume 12, Issue 4, October 2019, ISSN 1337-8384, eISSN 2453-711X 
2007; Fisher, Grant, Wilkinson, 2008; Kachkaeva, 2010; Zhang, 2008) and many others, each researcher has the different rational and emotional content regarding this word. All definitions, to a varying degree, differ from each other. Here are some examples. Spanish experts D. Domingo and R. Salaverría (2007) consider that "convergence is a many-valued concept that is used to describe various trends in media language. These trends have something in common: blurring the boundaries between different mass media, professional skills, and roles" (Domingo \& Salaverría, 2007). In the study guide "Media convergence and the "human situation": new challenges, old questions" we could find the following interpretation: the desire to merge the newsrooms and the audience is the "convergence" (Shayhitdinova, 2012; Marconi \& Siegman, 2017; Boeva-Omelechko et al., 2018). We can find a lot of such examples. All of them could be defined as faithful but very narrow and not capacious. Moreover, there are several approaches that describe the definition of "convergence", that are based on the description of various processes occurring at the different organizational levels of a media company (Kawamoto, 2003); perception of convergence as a gradual increase in cooperation with the print media, television and Internet portals (Dailey, Demo \& Spillman, 2005); the perception of convergence as a process leading to the technologies merging, the merging of previously different and disconnected media and markets (Vartanova, 1999, pp. 11-14) and others.

The authors of the article, who have been researching the field of media convergence for more than 10 years, offer the following definition: media convergence is a process in the modern media industry that had begun in the second half of the 1990s, at the period, when the media began to create their own Internet websites; it is associated with the technical achievements in the field of information transfer and its storage; while the process leads to the merging of previously different media (based on the Internet platform and / or convergent newsroom), departments and divisions of the media company in order to jointly produce content and replicate it on different media platforms; it has led to the appearance of the new types of media, new genres and forms of content, as well as to the global changes occurring at all stages - from creation to distribution of content, and the search for other models of media business development. However, our interpretation is also rather generalized. The abundance of different definitions and approaches to the description of media convergence attest the fact that it's impossible to create a definition, that is described just by the few words, and the reason of that is that the process of media convergence is associated not only with the global linguistic and extra-linguistic changes (Brinker, 1997) that occur at all stages from creation to distribution of media content and have their own specifics in different countries and regions of the world, but also with the transformation of the institution of media language that occurs at various levels of the media institutions: at the media language level as a sphere of creative activity, at the level of media language as a profession (journalism), at the level of media language as a media system, at the level of media language as a moral and ethical institution of the society, and at the level of media language as a sphere of business.

\section{Methodology}

Starting in 2008, the authors have studied the media market surveys, researches of various scientists dedicated to the development of the media convergence process. Authors have conducted expert interviews with media addressers as journalists and media managers of the Russian mass media. From the period of 2009 to 2018, 83 respondents from 29 media companies have been interviewed. We used the method of semi-formalized interview that appeals to the natural course of the respondent's thoughts, encouraging speaking freely on the proposed topic.

Expert surveys have been devoted to:

- Development of newspaper newsrooms and broadcast media newsrooms in the context of convergence. Duration: 2009, the period from 2012 to 2018; 46 people as 
media addressers from 29 media companies took part in the survey (editors of Internet versions, journalists, and top managers of Russian editions). Respondents were asked questions related to the development of Internet editions and other new divisions, the interaction between the Internet department and other divisions of the media company, the creation of broadcast media based on newspaper editorial, the development of multimedia content on websites, the development of mobile versions and new media platforms, new requirements for media addressers, the development of users content on websites (Thomas, 1995).

- Development of new forms of content distribution. Duration: from 2013 to 2018; 20 people from 17 media companies took part in the survey (authors of radio programs and top managers of Russian and foreign colloquial radio stations and TV channels, TV presenters, production studio employees, editors of Internet versions of Russian editions, web designers, infographics specialists). Respondents were asked questions related to the impact of the convergence process on reducing the timing of radio and television programs, the development of mini-rubrics on radio and $\mathrm{TV}$, the development of the Story genre on radio, the development of new genres and forms of providing content on Russian media websites, the development of infographics.

- Monetization of media business in terms of convergence. Duration: from 2012 to 2018, 17 people from 14 media companies took part in the survey (editors of Internet versions, employees of advertising departments, top managers of the Russian mass media). Respondents were asked questions related to the analysis of the possibilities of new media platforms as new sources of financial income for Media Company, the prospects of a business discourse strategy based on the use of user's resources (Gumperz, 1982); analysis of advantages and disadvantages in the process when transforming from a media company into a convergent media language / journalism.

When analyzing the data obtained as a result of surveys, information structuring has been used: open, axial, and selective coding.

The authors used the following theoretical methods: descriptive, comparative, sociological and statistical, comparative historical, historical and philological, structural, typological, hermeneutical, and linguocultural analyses.

\section{Results}

We concluded that today, we could distinguish two periods in transformation of media language under condition of media convergence.

I Period includes 3 linguistic and extra-linguistic stages:

1) Middle-second half of the 1990s. Internet versions of the media at this time websites, business cards, or full copies of the print editions in terms of content (generally traditional genres and linguistic means).

2) First-second half of the 2000s. There is a gradual transformation of media websites into independent multimedia resources with an increasing share of original (non-print, non-broadcast) content. Traditional media addressers - print or broadcast began to prepare content for online resources. New divisions and new positions appear in media companies. Media language in most cases remains traditional however appears more media messages with bright headlines containing emotional and expressional lexicon, epithets, metaphors, parenthetical constructions with uncertain semantics, etc. (Lakoff \& Johnsen, 2003)

3) From the second half of the 2000 s to the 2010 s, when the mass media are starting to develop new media platforms for distributing content (mobile, PDA, e-paper, kindle-versions, and from 2010 - versions for Tablets and Smartphones). Starting from the 2000s, there has been a merging of previously different types of media, and possibly other branches of the media business on the basis of one media (as a rule, on the basis of newspaper newsroom). The result of such process has become the newsroom that brought together media addressers from various media, working

XLinguae, Volume 12, Issue 4, October 2019, ISSN 1337-8384, eISSN 2453-711X 
together to produce content. Attempts to create convergent editions (which can be hindered by legislation on cross-media ownership) were primarily justified by the possibility of increasing labor productivity and increasing the number of "products" that are produced by the same number of employees; by distributing content through different media platforms, by the development of cross-media advertising.

The appearance of various mobile platforms, the growing popularity of social networks, and an overabundance of information led to the appearance and development of new verbal and nonverbal forms of providing and distributing a media language content based on the batch principle of presenting information, concise, capsule presentation of content (Zheltukhina et al., 2016a, 2016b). The appearance and development of new forms of content delivery has led to a trend related to surface information, reducing the possibility of creative implementation of authors, reducing the level of analytical research of information and to a general decline of the quality of media stories (content), the increasing prevalence of entertainment part of content, the pursuit of likes and more views of stories by users; as well as to the growth of brand journalism. Media language shows the violation of logic of statement of information, the lack of consecutive and reasoned analysis, and the existence of a large number of spelling and punctuation errors.

II Period (from 2013 to this day) is associated with the rapid implementation of smart-technologies in the media industry. The media began to try to use chatbots, wearable devices (Google Glass, smartwatches and bracelets) as new channels and platforms for content delivery, media started to think about using biometric technologies to highlight events. The media started to implement automated systems inside the newsrooms to search and distribute information faster. The question of what are the sequences of the rapid development of new technologies in mass media is still remaining open. Anxious predictions are causing concern, for example, that after 2020 the profession of a journalist may disappear.

Let analyze the features of the development of each of the period of the media language transformation under conditions of media convergence, taking into account the specifics of its occurrence in different countries.

\section{Period:}

\section{The 1990s.}

\section{The appearance of the first online media}

The beginning of the process of media convergence: the media are starting to develop their online versions. In 1994 - 1997, the Guardian, Telegraph, New-York Times, Izvestia, Nezavisimaya Gazeta, Kommersant websites appeared, the webpages of some radio stations appeared.

After a while, the online media that don't have any printed or broadcasted analog, are appearing. In 1999, the first Internet channel Broadcast.com was launched. The online media like newspapers Gazeta.ru, Polit.ru - one of the oldest political projects of the Russian Internet, Lenta.ru - a 24-hour news service providing a continuous stream of information about all significant events in Russia and abroad has appeared in Russia.

The Internet versions of the newspapers at this time are a complete analog of the stories of the print version; the broadcasting media websites, as a rule, are looking like business cards or trying to broadcast programs on the Internet. In 1994, the American channel $\mathrm{ABC}$ was the first in the world to start broadcasting on the Internet by organizing an online broadcast of the 'World News program.' In the same year, the website of the radio station Deutsche Welle appeared, it became a platform for text content and radio programs.

The economic crisis has become the impetus to the development and growth of the popularity of online media in the Russian Federation. On August 17, 1998, there has been a sharp drop in the ruble exchange rate. In the autumn, the ruble rates changed several times per day. Newspapers and even television and radio were not always able to produce and distribute the information quickly and accurately, but the actual 
information has been necessary to get to make quick decision-making in a crisis situation. But at the same time, the necessary and actual information could be found on the Internet. It was the right moment when online media proved its worth, and since that time the boom of creating various Internet websites and online media began in Russia. The elections of 1999 and 2000 have become one more impetus that led to the development of online media. Russian politicians have analyzed the experience of their American colleagues, who in 1996 realized the important role of the Internet in attracting the current audience.

In the counties with authoritarian regimes and a high level of poverty of the population, the media lagged behind in the development of Internet versions by an average of 15-20 years. For example, in Bangladesh, one of the poorest countries in Asia, the first experiments with television broadcasting on the Internet are related to 2009. At that time there has been the "live broadcast" rubric on the website of the Desh TV channel (Khan, 2015). Thus, broadcasting on the Internet began 15 years later than in the United States (ABC began broadcasting on the Internet in 1994). The first full-fledged Internet TV channel (ATN Music) in Bangladesh appeared only in 2014 (the same) (in the United States, the first professional Internet TV channel Broadcast.com was launched in 1999).

Development of websites of print media

In the first and second half of the 2000s, there was happening a gradual transformation of media websites into independent mass media. Video and audio content appears in Internet versions of newspaper publications. Audio content on the websites of many European and American newspapers was often presented in the form of podcasts - short one (8-10 min.) audio broadcasts on various topics. The Internet versions of Russian newspapers were not popular among Russian users; there were particularly none of them.

As for video content, it could be presented in the form of a short video illustrating the content of textual content, video columns of media addressers, video broadcasts from various events, etc.

Such development of newspaper websites was inevitable: after all, it was only with the help of interesting, diverse content that new users could be attracted, and, consequently, advertisers could be attracted. For example, the website Kp.ru, launched in 1997, had become financially reliable and then started to make a profit, only in 2006, when it began to turn into an independent multimedia resource (Baranova, 2017).

It was newspapers that were among the first major investors in online video - the appearance of video stories on print media websites increased the attendance of users. American publications began experimenting with audiovisual content on the websites as early as late 1990. Audiovisual content appeared on the websites of Russian newspapers later in 2006. For the period from 2009 to 2012 Russian newspaper websites have experimented with different forms of video content. However, in 2013 2014, the number of videos on websites began to grow down. For example, in 2009, media addressers of the newspaper and specialists from the Kommersant-Video group participated in the creation of video content on the Kommersant website. The website experimented with various formats of video content, but already in 2012 the editors have declined the idea that the media addressers created videos by themselves. The website declined to distribute different formats of video content, including video columns. As E. B. Golikova (the editor-in-chief of Kommersant-Online 2011 - 2013) explains, "Kommersant does not want to spend much time learning. It is necessary to simplify the approach to the digestibility of information. A video column needs to be watched, listened and understood at the same time - this is very costly from the point of view of learning the information" (Baranova, 2017).

In addition, "the Internet does not make it possible to live according to a schedule, so

XLinguae, Volume 12, Issue 4, October 2019, ISSN 1337-8384, eISSN 2453-711X 
if you develop a video content on the website, then you need to focus on the forms of video content" said P. Gusev, - editor-in-chief and the owner of the Moskovsky Komsomolets newspaper, - as practice shows, not all of the videos are in demand. Business videos are not gaining views, and even a well-known person cannot attract the user, and scandalous videos are also rarely becoming very popular. Users today do not stay long on the website; they are visiting the website to get the primary information, to write a comment. Most often they comment the videos on an erotic topic or videos based on some curiosity that can be well shared in social networks" (Baranova, 2017).

Media (in the hope of attracting a new audience to the website) at the end of 2010 begin to develop their pages in social networks. The development of social networks has led to the fact that nowadays, in the editorial offices (both mass and high-quality prints) they are more and more concerned with the "sharing" of content. This applies both to entertainment content and publications dedicated to serious topics.

Media addressers, as journalists and top managers of media companies, have gradually come to the understanding that a different format of presenting information is needed for an audience of social networks. Nowadays, the media addressers from the RT newsroom are making different content for every social network, they are making various visual stories according to requirements of current social network, for example, and media addressers are creating special news content for Facebook. They also are making montage of the video content especially for YouTube, inserting inside the video without comments and pieces of video that did not go on air.

With the development of social networks, the ever-increasing speed of life, the existence of the media in conditions of an overabundance of content has led to the development of infographics on media websites. World prints began to seriously develop this new direction in 2013 and 2014. In a situation of overabundance of information, one of the functions of media language has become the structuring of the data flow and the simplest and most visual reporting of information to the audience.

With the development of social networks, the media began to actively use the content produced by users. For the first time, the understanding that ordinary Internet users are able to inform faster than professionals came after the tragic events in the USA on September 11, 2001. At that time, popular bloggers began to collect and distribute all the information they could find on the Internet.

Nowadays, in the US and Europe, B2B companies (such as Newsflare, Jukin Media, Storyful, and others) are gaining more and more popularity, specializing in verification, licensing of user's video content, and subsequent resale to the world's leading mass media.

However, the majority of Russian mass media are still skeptical about the idea of using the user's content. The main issue is that the share of low-quality content is too high. It is about both the low quality of video and text content (unprofessionally written or filmed; banal, uninteresting), and about plagiarism.

A little later, the newspapers, the glossy magazines have been in the crisis associated with the advent of the Internet: in 2009 the sales of glossy magazines have fallen down by $20-25 \%$, the reason for that has become the appearance and widespread development of electronic magazines and newspapers. Many glossy magazines have launched online versions today, but, as a rule, it generally coincides with the print version.

\section{Development of Internet versions of broadcast media}

Internet versions of broadcast mass media also did not develop as actively as newspaper websites. The reason for that is that newspapers were the first to take over the crisis associated with the advent of the Internet, which provided an opportunity to read the news for free and without a subscription. If the possibility to read the text content on the Internet has been there at the start, then the opportunity to watch the video content did not appear immediately. Therefore, the crisis struck broadcasting 
corporations later in 2007 - 2010. It was at the time when they began to think about the serious development of websites. For example, when RT TV channel appeared in 2005 , they simply uploaded a video to the website, wrote a headline and a snippet of news. In 2007 - 2008 the website began to gradually to turn into an independent multimedia resource. Broadcasting content had become complemented by more comprehensive textual information, by various reference to content, twitter-reports of the TV channel correspondents. Today, every live video is complemented by stories that are provided only on the website. The news that is shown in life air as one plot could be represented in the form of dozens of stories related to each other.

Only some Russian radio stations (for example, Ekho Moskvy), only by 2010, began to turn into independent multimedia resources with a large share of original non-radio content.

Like radio stations, many television channels still have not solved the issue of filling their Internet resources with the content. For Internet versions of TV channels, there are two ways of development: a website as a platform for placing podcasts of programs, with the ability to watch live broadcasts (in Russia, for example, The 1 channel took this route), and as the website as a platform for hosting podcasts of programs with the ability to watch live plus as an independent news resource, where news is the main generator of website traffic. For example, the Internet version of the Russian television channel NTV followed the second path of development.

Development of online media versions and changes in the organization of newsrooms All media has faced such issues as preserving the existing audience and attracting new Internet users, reorienting journalists to work on the Internet when started to develop its own websites. With the development of media websites, changes have also occurred in the organization of newsrooms. New divisions appeared in the newsrooms - Internet departments or Internet newsrooms (web-departments), developing simultaneously with the development of online media versions. Internet newsrooms can be both: or include just a few people or can be a huge division.

Internet departments began their work as technology departments when 1-2 employees posted a copy of a newspaper or podcasts on the website. Over time, the newsroom offices began to identify individual media addressers who prepared various contents for the website, edited the content of the main newsroom staff, and supplemented it with photo and video content. In the newspaper editions appeared units, who were involved in the preparation and creation of audio-visual content.

In some newsrooms, the Internet departments turned into release services, bringing together programmers, designers, layout designers, and a huge staff of publishing editors, who gave tasks to media addressers of the main newsroom board. Issuing editors formed the look of the main and internal pages of the website, but in that case only the mainstream media addressers are engaged in the production and creation of content directly.

The development of Internet newsrooms has led to their close cooperation with the main newsroom, but the transition to work in the conditions of multimedia newsrooms is not necessary at all. Employees of the online newsrooms of many mass media nowadays are attending newsrooms' meetings. Media addressers, when planning the new issue of print media or the broadcasting schedule, ask the employee from the Internet department what is interesting on the website and on the Internet, what users are discussing in social networks.

Starting in 2010, social media editors began to appear in the mass media. Their main task is to properly "pack" content for a specific audience. Online, they track news, attach tags. In many newsroom offices, media addressers are motivated to independently advertise the content they produce in social networks.

With the development of the own Internet divisions, many mass media have encountered resistance to innovations from the media addressers' side. The issue was

XLinguae, Volume 12, Issue 4, October 2019, ISSN 1337-8384, eISSN 2453-711X 
that media addressers were used to produce the news in a way they made it for a long period of time, but the requirements for the preparation and creation the content for the Internet versions were different.

Newspapers had financial difficulties related to the development of their own team of media addressers, creating multimedia content for the website. The implementation of new content management systems (CMS) also required high financial costs. Software for newsrooms and advertising departments of media companies around the world has become absolutely necessary and widespread - without it; it is no longer possible to optimize the workflow and achieve professionalism.

2) From the second half of the 2000s to the 2010s. The further adaptive development of the media was facilitated by the appearance of new media platforms for the distribution of content, as well as changes in the way information has been used. The media began to appear for mobile, PDA, E-paper, Kindle versions, and since 2010 versions for Tablets and Smartphones have appeared.

The pioneers in the development of the mobile platform were Asian prints; this is due to the fact that in Asia countries (Singapore, Malaysia, Thailand, and Japan), the growth of the mobile industry market was originally observed. The Japanese newspaper 'AsahiShimbun' offered a mobile phone news delivery service as early as 1999. Asian mass media not only provided users with the ability to receive various content on their mobile phones but also actively offered to participate in news creation using a mobile phone. At the end of 2005, when many world prints were just beginning to get acknowledged with the mobile platforms, a new mobile interactive service of the Singapore-based issue 'The Straits Times' has been launched. It allows owners of Handphones to better interact with the newspaper to be its "ears" and "eyes." Via SMS, MMS users could send photos and information of any kind that could be considered as news. The versions for European mass media for mobile phones appeared only in the middle and the second half of the 2000s. The mobile versions provided access to all kind of the content regarding the latest updates (or access to selected sections); a service to receive many genres of media language: the latest news, local news, sports scores, politics and business news, stock quotes after the close of the day on world markets, weather reports, and advertising information.

In contrast to the broadcast media, print media, in parallel with the mobile applications started to develop versions of the newspaper for PDA, E-paper, and Kindle devices. The versions, as a rule, usually coincide with the printed ones.

With the development of iPads, iPhones, and portable devices based on Android, the mass media, starting from 2010, began to make special applications for them. Applications usually are providing access to the latest news and archival content, as well as to the multimedia content.

Applications developed for these devices, as a rule, have the possibility to download the content for offline reading / viewing / listening, support the content sorting function; it means it allows arranging media content in accordance with the interests of the user. Users of these applications can also share content using email, Facebook, Twitter.

At this phase, the mass media faced financial difficulties due to the development of mobile applications, as well as with the issue of finding good developers for such versions. Some media companies (for example, the MIA "Russia Today") created their own structural divisions and raised their own specialists. Many media decided not to develop an application for the mobile operating system (OS) but chose to create an adaptive layout of the website.

During the development of mobile applications, changes in the organization of the work of the editorial staff, as a rule, did not occur. Although there are a few examples of creating an own information service for preparing the latest news, which is broadcasting on the screen of mobile phones, or forming a team of media addressers who are preparing content for the iPad versions. For example, 'The Times,' when they 
created an advent of the tablet version, a team of 11 people began to work, creating its special content (Baranova, 2017).

However, many practitioners are sure that making a separate content for applications does not make much sense: there are many different stories and content, and usually, users read it mostly on the websites or in the social networks. Therefore it is more efficient to make diverse content for different social networks.

Since 2000 there is a merging of previously different types of media in different countries (and possibly other branches of the media business) on the basis of one media (as a rule, on the basis of newspaper editorial). The result of such a merger is often the appearance of a convergent (multimedia) editorial, bringing together media addressers from various mass media, and working together to produce content. This stage is most often associated with the union of the newspaper's editorial office (and applications), the website with the broadcasting resource (s) - the TV channel, and / or the radio station (possibly with the sales and cross-media advertising departments). At this stage of the convergence process nowadays there are some American, European and Russian mass media.

The development of the broadcasting resource itself (or resources) on the basis of a newspaper editorial, as a rule, is accompanied by a fairly strong resistance to innovations on the side of media addressers, as well as financial costs: the purchase of frequencies, new equipment, salaries for new employees, increase in the fund of reporters of newspapers, working to produce a content for various platforms, retraining costs. Media addressers at this stage are urged (if not obligated) to prepare content for other media. A combination of multi-functional media addressers and journalists preparing content for various platforms is also possible. An obstacle to the creation of a broadcasting resource on the basis of a newspaper editorial may be a restriction on the cross-ownership of the media.

In 2007 - 2010 all the attempts of creation of convergent newsrooms, first of all, were justified by the possibility of increasing labor productivity, increasing the number of "products" produced by the same number of employees, and potential reduction in the number of paid jobs, by combining the duties of several employees into the duties of one employee. However, in practice, it turned out that financial expenses are greatly increased, and the costs are not immediately paid off. In many ways, therefore, in 2014, the Komsomolskaya Pravda publishing house 'froze' stopped the development of digital TV, launched in 2011 by KP-TV. Planned as a new source of income, it brought only losses (Baranova, 2017).

Nevertheless, the convergence helped media companies to offer new opportunities for advertisers such as cross-media advertising, guaranteed contact with users on the website, the accurate segmentation of the audience, native advertising, and the share of what was increased significantly. The border between media language and branded content is increasingly lost nowadays.

Development of new forms of content distribution

The development of new platforms for the distribution of content, an overabundance of content, has led to the appearance of new forms of providing a media language (journalistic) content. Such forms of material presentation as "Some facts about ... (tips for ...)" stories in the form of "Question-answer," online tests became popular. With the development of media convergence, it has become quite difficult to fix the appearance or disappearance of new forms of content distribution. For example, the first Longreades that have been perceived as stories capable of satisfying lovers of "long" reading and "reader-scanners," as well as keeping the audience on the website appeared in 2012, but in 2016 its popularity began to fall down. Longreades remained in demand only as a genre of native advertising. In media language, mini-formats triumphed. With the increase of the flow of information, the popularity of the Twitter platform, many have changed the perception of the mass media language. For the

XLinguae, Volume 12, Issue 4, October 2019, ISSN 1337-8384, eISSN 2453-711X 
most part of consumers of information today, 140 characters are enough; people no longer want to know the details.

In the radio industry and in the television sphere, there are similar trends associated with the new principles of media language content delivery. There is a reduction in the timing of transmissions, mini-headings are appearing. This is due to the trend (which can be traced in different countries of the world) to a decrease in the average daily coverage of the general radio and television audience. The likely reason for this trend is the expansion of the number of new media channels for receiving information, which leads to a reduction in the consumption of traditional types of mass media.

We can say that nowadays, many mass media all over the world have come throughout the analyzed stages of the first stage. At the same time, there are not so many examples of when the media (as, for example, regional Russian printed media) still remains at the first stage of development of the media convergence process. The reason for that is often a lack of funding, as well as the unwillingness of management to bring changes.

\section{Period.}

The second stage of the development of the convergence process is associated with the rapid implementation of smart technologies in the media industry in 2013. At that period of time, some media started to use chatbots; wearable devices (Google Glass, smartwatches and bracelets) as a new channels and platforms for content delivery; started to think about the use of biometric technology for covering the events; as well as on the widespread implementation of automated systems into the work of newsrooms, allowing them to search, proceed and distribute information. The examples of the use of virtual reality technology for covering the events have appeared.

This development of the mass media is closely related to changes in the way information is consumed. Nowadays, everyone communicates with everyone (on Facebook, chat rooms, and chat applications) - this is one principle of perception of information. Another way of consuming information is one-on-one communication (the platforms have changed, but the principle has remained). Finally, there is a third way - getting filtered information.

The person, having appeared in a situation of information explosion, began to consume such amount of information which cannot be comprehended. Therefore, there is a need to filter it. Information users began to choose certain channels of information delivery for themselves and put restrictions on the content they receive. Chatbots in messengers offer exactly the same - news regarding the request.

With the appearance of wearable technologies, such as Google Glass, smartwatches and bracelets, foreign media began to try these devices as another platform for content delivery. For example, as soon as 'Google glass' appeared, CNN made a special application. This and other similar experiments have so far been unsuccessful. It is impossible to watch the news with one eye on a tiny screen and simultaneously perceive the sound with one ear. In addition, the quality of sound and video, for now, is poor.

It is not yet clear how to present the content on wearable technologies - these are very diverse devices. A person is binocular and must look with two eyes at the same time in order to perceive the whole environment, for example, not to get into an accident, while looking at the glasses. Human biology does not change as fast as technology. Wearable electronics is still a utilitarian thing. Maybe you need "smart" headphones that will report the arrival of the news and ask whether you want to listen to it or not. But constantly a person will not wear the headphones; he will not be able to listen to the big amount of news. Moreover, the news that was automatically read is not accepted as news. It is also pointless to attract a special announcer for this.

As for watches and bracelets, there also comes a snippet (a heading with a maximum 
length of 100 characters), but you need to read or watch the news, again, using some device - a phone, a tablet.

Till now, there is no understanding of the way of delivering the news to such devices, so that it could be really useful and profitable to the news organization and to the consumer.

Here, the words of the futurologist Toffler can be pronounced that no one can say with the absolute certainty "where will all these discoveries lead and that in real life they will turn into a profitable product or service that people will want" (Toffler, Toffler, 2008).

Nowadays, the media business is faced with two trends: the constant growth of news and the lack of human resources to cover them. The response of the world's major mass media to this challenge of modernity was the implementation of automated systems into the work of editors who independently produce content (news, infographics, and video).

The pioneer in the use of smart technologies in media language has become the Associated Press agency. In the summer of 2013, the heads of the news department of this media company offered to use the technology of artificial intelligence to automate the process of creating news content.

The experience of the leading news agencies in the implementation of automated systems into the content production systems shows that media addressers-robots are not helping to reduce costs by dismissing a number of employees, real people. Automated systems only help to reallocate editorial resources for content production.

Representatives of the foreign mass media also note that the implementation of robots entails high operational costs for automated products. Access to data for its subsequent automation often depends on third-party suppliers and official sources, and some foreign information agencies have to pay for these data (Fanta, 2017).

The use of smart technologies in the media industry is closely related to the development of data journalism. This is a type of media language, that bases its investigations on data (opened and collected by media addressers) and on their investigation by computerized methods.

Nowadays, everything consists of the generated data; any actions of the state, political or public organization are recorded. Data becomes open. There is a need for them to be correctly understood and presented. On the basis of these data, patterns and trends should be identified.

The editorial staff of the 'Los Angeles Times,' 'The Guardian,' 'Wyborcza,' and other world mass media have introduced special programs that analyze the reports of numerous departments and services, and examine archives.

In Russia, the date of media language is just beginning to develop. If we compare the world mass media and Russian, we can say that the data departments appeared in first mass media has already appeared a few years ago, and in Russia it appears only nowadays. In June of 2018, such a department appeared in 'Novaya Gazeta.'

In the spring of 2018, the staff of the data department of 'Novaya Gazeta' analyzed 60,000 verdicts of Russian courts related to extremist crimes. It was possible to reveal an interesting tendency: the courts deliberately eliminate the qualifying extremism signs, because, as a rule, they are contrived. Society does not understand what extremism is and what is not. Without a data department, such stories cannot be created.

At the same time, the dependence of data journalism on whether data is available or not makes its development impossible in some countries where there is no open data there.

Artificial intelligence can allow media addressers not only to analyze data, establish patterns but also to notice what is impossible to see with the 'naked' eye: to understand and recognize feelings. For example, a media address obtains an interview

XLinguae, Volume 12, Issue 4, October 2019, ISSN 1337-8384, eISSN 2453-711X 
with an official, and a voice analysis device tells you that he is unsure or nervous.

Media addressers of the 'Quartz' news website, when telling about Donald Trump's speech, used the technology of biometrics, at the end of January 2017. The implementation of the technology of artificial intelligence allowed to analyze the facial expression and emotions of the president. The machine recognized microexpressions (for example, raising the eyebrows as an indicator of surprise) and then equated these micro-expressions with pre-determined emotions (Toffler, Toffler, 2008).

If the use of biometric technologies in media language is still of a single character, then examples of the use of virtual reality technology are increasingly being used to cover different events. The journalist Nonni de la Peña, who made a cycle of documentaries using the Oculus Rift glasses, among her colleagues, is named "the godmother of virtual reality." One of her famous projects, - 'Use of Force,' is dedicated to the issue of immigration. A native of Mexico, he lived with his family in the United States for almost 30 years but was ordered to be deported by American authorities. He tried to return and was beaten to death by border guards. The incident was recorded on several video cameras. Virtual reality gives viewers the opportunity to witness this tragic event.

\section{Discussion}

There is no definitive answer to the question of what the process of media convergence and further development of technologies will lead to and how it will affect the media language, media discourse, and journalism.

However, it can be stated: our cognitive mechanisms do not keep pace with the development of technology. Therefore, cognitive distortion appears. The human brain does not change as fast as technology changes. The Greek philosopher Socrates once even protested against the development of any technology that would allow people to easily express their thoughts in writing, stating: "The written word is the enemy of memory" (Baranova, 2017). Centuries later, Johannes Tritemius, a German cryptographer, said that the printing press would harm the monks responsible for the correspondence of religious texts (Baranova, 2017). The typewriter and even the modern word processor also had skeptics. Now concerns are also caused by the widespread implementation of media addressers-robots into editorial work (Toffler \& Toffler, 2008). Nevertheless, there are opinions that the use of smart technologies saves media addressers from solving boring, routine tasks, and increases the reporters' ability to understand and precede the ever-increasing amount of data.

And yet, when implementing the automated systems into the work of editorial offices, which allow not only to independently produce content, but also to analyze information, it is necessary to understand that "not a single machine can, for example, look at the connection between the two organizations, think: "This is strange" or to make appropriate calls, talk to the right people, or do the research necessary to come to an objective result" (Toffler, Toffler, 2008).

Artificial intelligence can help empower opportunities of the media addresser, save them from routine work, but this technology is not yet able to take the creative part of his work.

So there are many types of media addresser in the media language. In Moscow and other large cities, a huge number of people call themselves journalists, although they are not: they simply rewrite the texts of news agencies. This work can be done by a robot. Perhaps journalists as media addressers today need to come to the essence they should get information and not rewrite the information that has been already published by someone. To do this, they must walk with their feet, fly planes, and be able to communicate with people, analyze documents. 


\section{Conclusion}

The process of media convergence led to the transformation of the institute of media language at different levels: at the level of media language as a sphere of creative activity, media language (means journalism) as a profession, media language as a media system, media language as a moral and ethical institution of society, media language as a business sphere.

The concept "media language / journalism" is often replaced by a large number of words with the prefix "media," it becomes less and less a creative activity. Stories that require creativity are less and less in demand by the audience. Media addressers are increasingly engaged in rewriting, compiling content available on the Internet regarding the specific format - stories (often entertaining or commercial), based on the package principle of presenting information and concise, capsular content delivery. The news about an event is increasingly gaining much more views, likes, comments than even a short (no more than 5000 characters) interview on the same topic. It is unlikely that rewriting (which today is the basis of many media stories) can be called creativity. Competition in the media market, associated with the increasing influence of the Internet and social networks, leads to deterioration in the content of the mass media. Media products are worse processed, edited; they are often factual errors and errors associated with the violation of the language norms.

Media convergence is reducing the creative activity of a media addresser. This is evidenced by dozens of interviews conducted by the authors in the period from 2009 to 2018, with experts from major Russian mass media.

According to the ASI forecast, the "media addresser (journalist)" as the profession should disappear after 2020, since artificial intelligence can solve $95 \%$ of the tasks associated with creating a media product.

The concept of "journalist" also became quite ambiguous. Numerous bloggers, often without professional education and media experience, have reached a mass audience. Today, a blogger as media addresser is equal in everything to a journalist, with the only difference that there are no editors above the first one.

However, regular media addressers of registered mass media nowadays are posting lot of news on the websites that often don't pass either editorial checking or proofreading: today's publishers simply do not have time to manipulate with the text. In this regard, the cost of mass media responsibility under the reader, viewer and listener increases.

The overall level of falling of the quality of media stories is also explained by the economic difficulties that the mass media faced as a result of the development of the convergence process.

Initially, media convergence was concerned as a new model for the development of the media business, offering new advertising and PR opportunities that would allow finding new sources of profit. The development of convergent media language or convergent journalism, that involves combining various verbal or nonverbal forms of content delivery and distributing it among different media platforms, of course, provides new opportunities for advertisers. This, in particular, leads to the fact that native advertising and branded content in the media is becoming more and more popular. In this regard, the functions of media language are transformed: the advertising and reference function comes to the fore along with the informational one. 
Nowadays, the commercial projects dedicated to the delivery of quality content are better than free content, and this is understandable: much more time, labor, and financial resources are spent on its creation. But we must not forget that the media advertiser is often embedded in the process of creating content, depriving media addressers of creative activity.

\section{Acknowledgments}

1.The publication has been prepared with the support of the RUDN University Program 5-100.

2.The work is performed according to the Russian Government Program of Competitive Growth of Kazan Federal University.

\section{Bibliographic references}

BARANOVA, E.A. 2017. Convergence of Media Lips of Experts Journalists: Monograph. Moscow: Prometheus.

BOEVA-OMELECHKO, N.B. - ZHELTUKHINA, M.R. - RYABKO, O.P. MATVEEVA, G.G. - MURUGOVA, E.V. - ZYUBINA, I.A. 2018. Unusual Antonyms: Inter-Part-Of-Speech Interaction in English Fictional Discourse. In: Space and Culture, India, vol. 6, no. 4, pp.112-121. eISSN 2052-8396.

BRINKER, K. 1997. Linguistische Textanalyse. Eine Einfuehrung in Grundbegriffe und Methoden. Berlin: Erich Schmidt. ISBN 103503037810

DAILEY, L. - DEMO, L. - SPILLMAN, M. 2005. Most TV/Newspapers Partners At Cross Promotion Stage. In: Newspaper Research Journal, vol. 26, no. 4, pp. 36-49.

DOMINGO, D. - SALAVERRÍA, R. 2007. Four Dimensions of Journalistic Convergence: A Preliminary Approach to Current Media Trends at Spain. In: 8th International Symposium on Online Journalism. Austin, Texas (EEUU), pp. 1-7.

FANTA, A. 2017. Putting Europe's Robots on the Map: Automated journalism in news agencies. Available online: https://reutersinstitute.politics.ox.ac.uk/sites/default/files/2017-

09/Fanta\%2C\%20Putting\%20Europe\%E2\%80\%99s\%20Robots\%20on\%20the\%20M ap.pdf (date of access: 28.12.2017).

FISHER, D. - GRANT, A. - WILKINSON, J. 2008. Principles of Convergent Journalism. Oxford: Oxford University Press. ISBN: 9780195339246

GUMPERZ, J.J. 1982. Discourse Strategies. Cambridge: Cambridge University Press. ISBN-13: 9780521288965. ISBN-10: 0521288967.

KACHKAEVA, A.G. 2010. Journalism and Convergence: Why and How Traditional Media are Transformed into Multimedia. Moscow: FOCUS-MEDIA.

KHAN, M.A.K. 2015. The Internet Television in Bangladesh: the Current State and the Prospects of development. In: Mass Media in the Multipolar World: Problems and Prospects: Proceedings of the VI All-Russian Scientific and Practical Conference. Moscow: RUDN.

LAKOFF, G.N. - JOHNSEN, M. 2003. Metaphors We Live By. Chicago: The University of Chicago Press. ISBN-13: 9780226468013. ISBN-10: 0226468011.

MARCONI F. - SIEGMAN, A. 2017. The Future of Augmented Journalism: A Guide for Newsrooms in the Age of Smart Machines. In: El profesional de la información, vol. 27, n. 4, pp. 751-758. eISSN: 1699-2407

QUINN, S. - FILAK, V.F. 2005. Convergent Journalism an introduction. Amsterdam:

Focal Press. ISBN, 97802408072490240807243. 
SHAYHITDINOVA, S.K. 2012. The Media Convergence and the "Human Situation": New Challenges, Old Questions. Kazan: Kazan University Press. ISBN 978-5-8044$1642-4$

THOMAS, J.A. 1995. Meaning in Interaction. An Introduction to Pragmatics. London: Longman. ISBN-13: 9780582291515. ISBN-10: 0582291518.

TOFFLER, E. - TOFFLER, Ch. 2008. Revolutionary Wealth. Moscow: AST.

VARTANOVA, E.L. 1999. To what Convergence in Media Conducts. In: Information Society, vol. 5, pp. 1-14.

ZHANG, Y.E. 2008. Examining media convergence: Does it converge good journalism, economic synergies, and competitive advantages? PhD Thesis. Columbia: University of Missouri.

ZHELTUKHINA, M.R. - KRASAVSKY, N.A. - PONOMARENKO, E.B. ALESHCHANOVA, I.V. - PAVLOV, P.V. 2016a. Political Facebook Posts Using Ideological Symbols for Media Image Designing of Russia as Enemy. In: International Journal of Environmental and Science Education, vol. 11, no. 18, pp. 12005-12013. ISSN 1306-3065.

ZHELTUKHINA, M.R. - SLYSHKIN, G.G. - PONOMARENKO, E.B. BUSYGINA, M.V. - OMELCHENKO, A.V. 2016b. Role of Media Rumors in the Modern Society. In: International Journal of Environmental and Science Education, vol. 11, no. 17, pp. 10581-10589. ISSN 1306-3065.

Words: 8800

Characters: 56760 (31,53 standard pages)

Mauye K. Adyrbekova

Department of Foreign Philology

Kazakh Ablai Khan University of International Relations and World Languages

200 Muratbayeva Street

050022 Almaty

Kazakhstan

adyrbek_mauye@mail.ru

assoc. prof. Ekaterina A. Baranova, $\mathrm{PhD}$.

Communicative Management Department, Journalism Chair

Russian State Social University

4/1 Wilhelm Pieck Street

129226 Moscow

Russia

kat-journ@yandex.ru

Anna A. Shnaider, PhD.

Institute of Philology, Department of Mass Communications

Peoples' Friendship University of Russia (RUDN University)

6 Miklukho-Maklaya Street

117198 Moscow

Russia

anshnaider@gmail.com

XLinguae, Volume 12, Issue 4, October 2019, ISSN 1337-8384, eISSN 2453-711X 
prof. Albina R. Shaidullina, DrSc.

Department of Foreign Languages

Almetyevsk State Oil Institute

2 Lenin Street

423450 Almetyevsk

Russia

albina-plus@mail.ru

assoc. prof. Elvira K. Sabaeva, PhD.

Department of Humanities Education and Sociology

Almetyevsk State Oil Institute

2 Lenin Street

423450 Almetyevsk

Russia

kfn_agni@rambler.ru

prof. Anvar N. Khuziakhmetov, DrSc.

Institute of Psychology and Education

Kazan (Volga region) Federal University

18 Kremlyovskaya Str.

420008 Kazan

Russia

hanvar9999@mail.ru 